\title{
Different levels of shade on population of grasshoppers and its oviposition preference on heliconias
}

\author{
Ana Cristina Bittar ${ }^{1}$ Elen de Lima Aguiar-Menezes ${ }^{2 *}$ José Guilherme Marinho Guerra $^{3}$ \\ Janaína Ribeiro Costa Rouws ${ }^{3}$ Luiz Augusto de Aguiar ${ }^{4}$ Paulo Sergio da Silva Leite ${ }^{1}$
}

\footnotetext{
${ }^{1}$ Programa de Pós-graduação em Agricultura Orgânica, Universidade Federal Rural do Rio de Janeiro (UFRRJ), Seropédica, RJ, Brasil.

${ }^{2}$ Departamento de Entomologia e Fitopatologia, Universidade Federal Rural do Rio de Janeiro (UFRRJ), 23897-000, Seropédica, RJ, Brasil. E-mail: emenezes@ufrrj.br. "Corresponding author.

${ }^{3}$ Embrapa Agrobiologia, Seropédica, RJ, Brasil.

${ }^{4}$ Empresa de Pesquisa Agropecuária do Estado do Rio de Janeiro, Centro Estadual de Pesquisa em Agricultura Orgânica, Seropédica, RJ, Brasil.
}

\begin{abstract}
Grasshoppers of the families Acrididae and Romaleidae (Orthoptera) are among the insects that defoliate heliconias and have been gaining status as pests of commercial crops of these plants in Brazil. The objectives of the present study were to identify the grasshopper defoliating heliconias in the municipality of Santo Antônio de Pádua, RJ (Brazil), to evaluate the effect of different levels of shade on the population of this grasshopper and the production parameters of heliconias, and to determine if this grasshopper has an oviposition preference among the heliconias evaluated. The experiment was in a completely randomized block design, in subdivided plots (four levels of shade in the plot, $0 \%, 30 \%, 50 \%$ and $80 \%$, and four species of Heliconia: H. psittacorum, H. stricta, H. wagneriana and H. psittacorum $x$ H. spathocircinata 'Golden Torch' in the subplot), with four replications. The grasshopper was identified as Cornops frenatum frenatum (Acrididae). An increase in shade resulted in a decrease in the number of oviposition holes from the grasshopper and the number of lateral buds. Shade did not influence the number of C. f. frenatum nymphs and adults and the number of flower stems. H. wagneriana was the most preferred species for oviposition by $C$. $f$. frenatum. Results suggested using screens to shade heliconia plants can help control C. $f$. frenatum populations, however, the light requirements of the heliconias should be considered to guarantee productivity.
\end{abstract}

Key words: Orthoptera, Cornops frenatum frenatum, oviposition behavior, tropical flowers, Heliconiaceae.

Diferentes níveis de sombreamento na população de gafanhotos e sua preferência para oviposição em helicônias

RESUMO: Os gafanhotos das famílias Acrididae e Romaleidae (Orthoptera) estão entre os insetos desfolhadores de helicônias, e vem ganhando status de pragas em cultivos comerciais dessas flores no Brasil. O presente estudo objetivou identificar o gafanhoto de ocorrência no município de Santo Antônio de Pádua, RJ (Brasil) causador de desfolhamento em helicônias; avaliar o efeito de diferentes níveis de sombreamento sobre a população desse gafanhoto e parâmetros produtivos de helicônias; e se existe preferência do gafanhoto para oviposição entre as helicônias avaliadas. O experimento foi em delineamento em blocos ao acaso, em esquema de parcelas subdivididas (quatro níveis de sombreamento: $0 \%, 30 \%, 50 \%$ e $80 \%$ na parcela e quatro espécies de Heliconia: H. psittacorum, H. stricta, H. wagneriana e H. psittacorum $x$ H. spathocircinata 'Golden Torch'na subparcela), com quatro repetições. O gafanhoto desfolhador foi identificado como Cornops frenatum frenatum (Acrididae). À medida que o sombreamento se tornou mais denso, diminuíram o número de orificio de oviposição do gafanhoto e o número de brotações laterais. O sombreamento não influenciou o número de ninfas e adultos de C. f. frenatum e o número de hastes florais. H. wagneriana foi a espécie mais preferida para oviposição por C. f. frenatum. Os resultados sugerem que o uso de tela para sombreamento das plantas de helicônia pode auxiliar no controle da população de C.f. frenatum, porém, deve-se observar o padrão de exigência de luminosidade das helicônias para garantir a produtividade.

Palavras-chave: Orthoptera, Cornops frenatum frenatum, comportamento de oviposição, flores tropicais, Heliconiaceae.

\section{INTRODUCTION}

The family Heliconiaceae contains only one genus, Heliconia L., which includes some of the main cut flower species of tropical floriculture
(WARUMBY et al. 2004; NEVES \& PINTO, 2015). The production chain of cut or potted flowers and ornamental plants is incredibly important to the Brazilian economy, with revenue of $\mathrm{R} \$ 5.41$ billion in 2014. Of this, the state of São Paulo was responsible 
for the largest amount ( $\mathrm{R} \$ 1.98$ billion). The state of Rio de Janeiro has become the second largest producer in this sector with revenue of $\mathrm{R} \$ 594$ million in 2014, of which $48 \%$ was from the commercialization of cut flowers and foliage, mainly after investments from the government of this state through the Programa de Apoio à Floricultura - Florescer (NEVES \& PINTO, 2015). In addition, floriculture in Rio de Janeiro State has been expanding to new areas, especially in the northeastern (MACHADO NETO \& JASMIM, 2012; NEVES \& PINTO, 2015).

Since 2004, different species of certified organic heliconias cultivated in the municipality of Santo Antônio de Pádua, in northeastern Rio de Janeiro, have suffered significantly from defoliation by a grasshopper (Orthoptera). While inspecting clumps of cultivated heliconias, differences in levels of defoliation were observed of plants growing in full sun, which appeared more damaged compared to those in the shade provided by other plant species (e.g., of trees). This led to the suspicion that shade might influence the infestation of the grasshopper.

In Brazil, defoliating grasshoppers in the genus Schistorcerca Stal. (Orthoptera: Acrididae, Cyrtacanthacridinae) have been reported as heliconia pests in the state of Pernambuco (WARUMBY et al., 2004). In Manaus, AM, heliconias are cited as native host plants of Cornops frenatum frenatum (Marschall, 1835) (Orthoptera, Acrididae, Leptysminae) (ADIS et al., 2007; BRAGA et at., 2007). LEMOS et al. (2010) reported that this grasshopper species as the main defoliator of commercially cultivated heliconias in northeastern Pará, and emphasized the need for studies about the biological aspects of this insect pest to develop control measures. In Bahia, MATTOS SOBRINHO et al. (2012) reported the lubber grasshopper Tropidacris collaris (Stoll) (Orthoptera: Romaleidae) as a defoliator of heliconias. Prionolopha serrata L. and Chromacris speciosa Thunberg (Orthoptera: Romaleidae) are two other species of lubber grasshoppers reported to cause significant defoliation in commercial heliconia plantations in Pará, as well as Eutropidacris cristata L. (Orthoptera: Acrididae) (RIBEIRO et al., 2013).

The present study had the following objectives: i) identify the grasshopper species in the municipality of Santo Antônio de Pádua that is defoliating heliconias, ii) evaluate the effect of different levels of artificial shade on the population of these grasshoppers and productive parameters of the heliconias, and iii) determine if this grasshopper has an oviposition preference among the heliconias evaluated.

\section{MATERIALS AND METHODS}

The study was conducted from March 2012 to February 2013 , on a rural property $\left(21^{\circ} 28^{\prime} 56.5^{\prime \prime} \mathrm{S}\right.$, $42^{\circ} 03^{\prime} 10.2^{\prime \prime} \mathrm{W}$, elevation $82 \mathrm{~m}$ ) in the district of Monte Alegre, Santo Antônio de Pádua municipality, RJ (Brazil). On the property, certified organic tropical flowers (including heliconias), foliage, fruits and other plants, such as açaí palm (Euterpe oleracea Mart., Arecaceae), are produced.

The heliconias were submitted to three levels of shade, $30 \%, 50 \%$ and $80 \%$, as well as full sun $(0 \%)$. To create the shade, black screens (Sombrite ${ }^{\circledR}$ ) were sewn into iron frames to construct shade houses, which were $1.20 \times 1.20$ and $1.30 \mathrm{~m}$ tall, with an opening in the front so data could be collected. For each shade house, a $50 \mathrm{~cm}$ iron frame extension was added so it could become $1.80 \mathrm{~m}$ tall, which allowed it to be adjusted based on the size of the heliconia plants evaluated. A $50 \mathrm{~cm}$ strip of screen was added to three sides of the extension. The front was left open to allow insects to enter. The openings of all the shade houses pointed toward the east (sunrise) and the structures were arranged in an experimental area where they did not shade each other.

Four species of Heliconia were evaluated: $H$. psittacorum L.f., $H$. stricta Huber and $H$. wagneriana Petersen and $H$. psittacorum L.f. x $H$. spathocircinata Aristeg. 'Golden Torch' (natural hybrid). The smaller heliconias ( $H$. psittacorum and 'Golden Torch') were planted in 5 -liter (25cm diameter) plastic containers and the larger heliconias ( $H$. stricta and $H$. wagneriana) were planted in 8-liter $(35 \mathrm{~cm}$ diameter) containers. Young plants were removed from mature clumps (which were under cultivation on the property where the experiment was conducted) by sectioning the rhizome. They were then planted in the containers with a mixture $(1: 1)$ of road bank soil and organic compost. The bottoms of the containers were lined with decomposing wooden trunks to allow for drainage, following routine methods for seedling production on the property. After 60 days, which allowed the young plants to become established and new leaves to emerge, the plants were taken to the area of the experiment and placed on cement blocks, so weeds could be removed with a trimmer.

The experiment was in a randomized block design with four plots divided into subplots. In each plot four levels of shade were randomly assigned, and each plot was subdivided to include the four species of heliconia. Two containers of each heliconia were placed in each experimental subplot, 
totaling eight containers per plot. The potted heliconia plants were randomly placed in the shade houses on 16 February 2012. Data collection began on 01 March 2012, after the plants had two weeks to adapt to the shade or sun conditions.

Number of adults, nymphs, oviposition holes from the grasshopper and number of lateral buds (shoots) and flower stems per plant of each heliconia species for each level of shade were recorded weekly for 54 weeks. After counting, adults of the grasshopper were collected manually, placed in mesh bags, killed and pinned. Some specimens were sent to the Laboratório de Ecologia e Taxonomia de Insetos, at the Universidade Federal do Recôncavo da Bahia (Cruz das Almas, BA, Brazil), for identification. Nymphs of the grasshopper were killed at the study site. The flower stems were harvested when they had three open bracts and dry lateral buds were cut.

The data for each heliconia species and respective shade levels for average number of adults (A), nymphs (N), oviposition holes (O), flower stems produced $(\mathrm{F})$ and lateral buds $(\mathrm{B})$ (average of two repetitions for each species per plot) did not meet the assumptions of the analysis of variance, even after the data was transformed (Lilliefors and Cochran at $1 \%$ ), using the program $\mathrm{SAEG}^{\circledR}$ version 9.1. Data were evaluated using Friedman's nonparametric test and the program STATISTICA ${ }^{\circledR}$ version 5.0. Subsequently, Kendall's concordance coefficient $(W)$, with a $5 \%$ significance level, was applied. The statistical differences were tested with the H1 (among the four levels of shade), H2 (among the four heliconia species) and H3 (interaction among the levels of shade for each heliconia) hypotheses. The first hypothesis was established to generically evaluate the effect of each level of shade on the variables $\mathrm{A}, \mathrm{N}, \mathrm{O}, \mathrm{F}$ and $\mathrm{B}$. The second hypothesis investigated how the variables behaved within each species of heliconia, independent of the level of shade, and the third hypothesis verified if there was interaction. The significance was evaluated by calculating the minimum significant differences for each pair of data averages $\left(\Delta_{\mathrm{ij}}\right)$.

\section{RESULTS AND DISCUSSION}

The defoliating grasshopper was identified as Cornops frenatum frenatum (Marschall, 1835) (Orthoptera, Acrididae, Leptysminae). This species was already recorded for the state of Rio de Janeiro, but this is the first record for Santo Antônio de Pádua (ADIS et al., 2007; ASSIS-PUJOL \& PUJOL-LUZ, 2014). Nymphs have a bluish-green body and orange stripes, including the legs (Figure 1). They have a gregarious habit and are found in groups on the leaves, mainly in the first instar, and then are lodged in the coiled unopened leaves ("cigar"), before the opening of them, as already described by LEMOS et al. (2006; 2010). The body of adults is green in color, has a dark brown stripe on the side of the body from the head to the mesothorax, their wings are brownish (female) to green (male), with dark brown side edges, and orange antennae (Figure 1). Females are relatively larger than males, as observed by LEMOS et al. (2006; 2010), who cited the size of $25.8 \pm 0.07 \mathrm{~mm}$ and 16.4 $\pm 0.12 \mathrm{~mm}$, respectively.

All the heliconias were infested with adults and nymphs of $C$. $f$. frenatum, which used the plants as a food source, shelter, mating place and for oviposition, and the leaves of the plants were damaged to a greater or lesser degree. These heliconias were recorded as host plants of this grasshopper by LEMOS et al. (2006) and BRAGA et al. (2007). During the experimental period, 4,327 nymphs of $C$. $f$. frenatum were encountered on the 128 plants of the experiment, as well as 636 adults of this grasshopper, whose females endophytically lay eggs in the pseudostem of the heliconias, as reported by BRAGA et al. (2007).

In relation to the different levels of shade, the following $C$. $f$. frenatum were reported on the heliconia plants: 204 adults and 1,244 nymphs (32.0\% and $28.8 \%$ of the total collection of each development stage, respectively) for the heliconias in full sun; 174 adults and 927 nymphs (27.4\% and $21.4 \%$, respectively) under the condition of $30 \%$ shade; 183 adults and 1,480 nymphs under $50 \%$ shade $(28.8 \%$ and $34.2 \%$, respectively); and 75 adults and 676 nymphs $(11.8 \%$ and $15.6 \%$, respectively) under $80 \%$ shade. Results suggested $C$. f. frenatum adults prefer full sun, which is possibly because grasshoppers, in general, are classified as heliothermic insects and need to absorb a lot of solar energy to fly, feed, mate and oviposit (LACTIN \& JOHNSON, 1997). The nymphs demonstrated a preference for partial shade, probably because they have a more delicate tegument compared to adults.

In relation to the heliconias, the total number of grasshoppers for the two development stages was the following: $H$. psittacorum, 32 adults and 293 nymphs $(5.0 \%$ and $6.8 \%$ of the total collected of each stage, respectively); H. psittacorum x H. spathocircinata 'Golden Torch', 92 adults and 588 nymphs (14.5\% and $13.6 \%$, respectively); $H$. stricta, 218 adults and 689 nymphs $(34.3 \%$ and $15.9 \%$, respectively); and $H$. wagneriana, 294 adults 


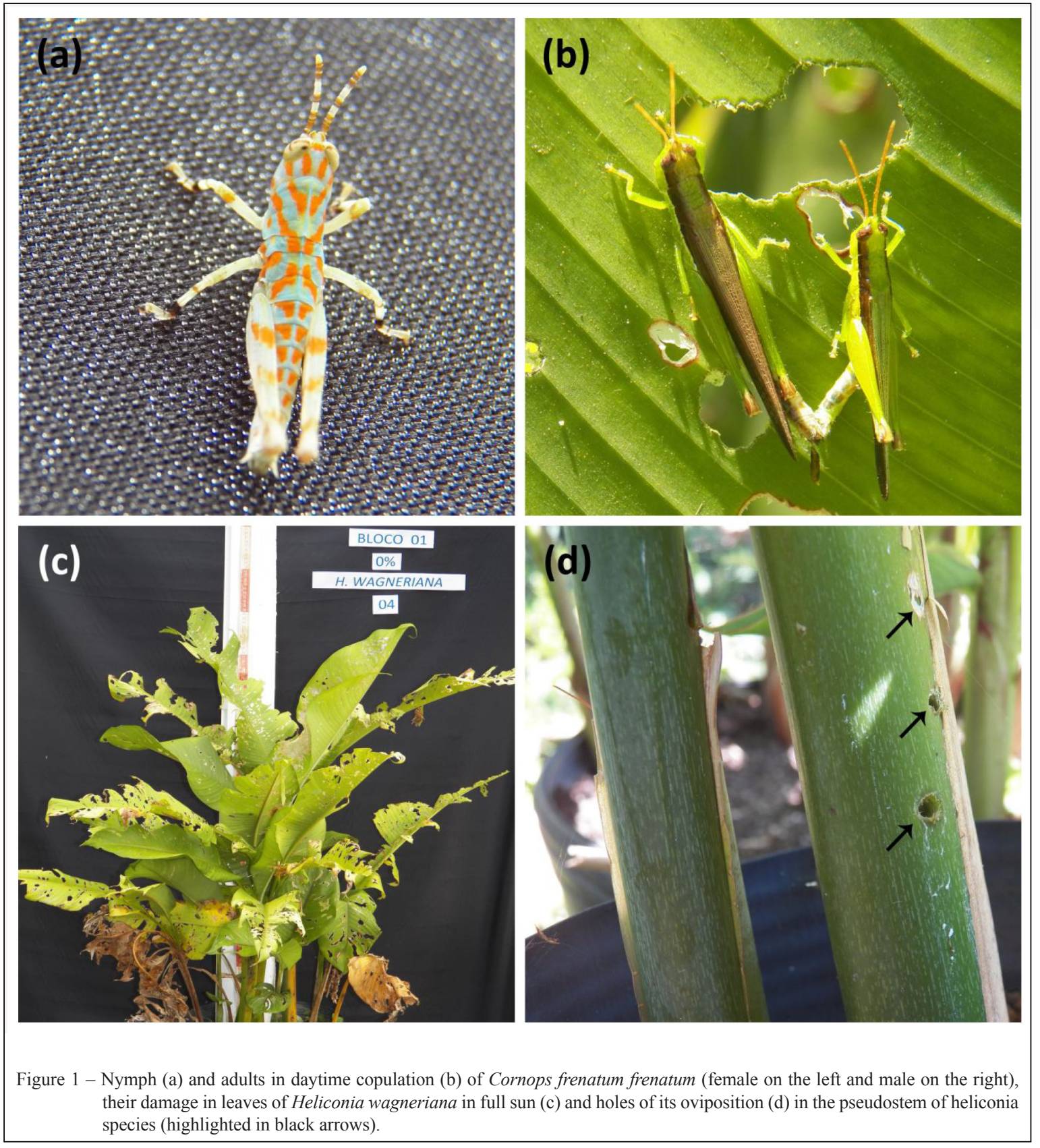

and 2,757 nymphs (46.2\% and $63.7 \%$, respectively). These results suggested that the latter species of heliconia is more attractive to this insect, and possibly preferred more for feeding and oviposition (Figure 1).

There was no significant interaction between the levels of shade tested for each heliconia species (hypothesis H3). The significant difference between the average values of the biological data of the grasshopper and production of the plants of each heliconia species was tested by hypotheses $\mathrm{H} 1$ and $\mathrm{H} 2$.

Hypothesis H1: there was a difference between the levels of shade tested. The level of shade did not interfere with the number of adults and nymphs of $C$. $f$. frenatum and the number of flower stems (Table 1). Shade level only interfered with oviposition behavior of the grasshopper and number of lateral buds produced by the heliconias. In general, 
Table 1 - Average values of the Friedman ANOVA and Kendall's concordance coefficient $(W=0.84 ; \mathrm{N}=4, \mathrm{DF}=3)$ for the number of adults (A), nymphs (N) and oviposition holes (O) of Cornops frenatum frenatum and the flower stems (F) and lateral buds (B) of heliconias in different levels of shade, from March 2012 to February 2013, in Santo Antônio de Pádua, RJ.

\begin{tabular}{|c|c|c|c|c|c|}
\hline \multirow[t]{2}{*}{ Level of shade $(\%)$} & \multirow[b]{2}{*}{$\mathrm{A}^{\mathrm{ns}}$} & \multirow[b]{2}{*}{$\mathrm{N}^{\mathrm{ns}}$} & \multirow[b]{2}{*}{$\mathrm{O}^{*}$} & \multirow[b]{2}{*}{$\mathrm{F}^{\mathrm{ns}}$} & \multirow[b]{2}{*}{$\mathrm{B}^{*}$} \\
\hline & & & & & \\
\hline 0 & 0.53 & 3.24 & $3.85 \mathrm{a}$ & 0.32 & $9.49 \mathrm{a}$ \\
\hline 30 & 0.45 & 2.41 & $2.71 \mathrm{ab}$ & 2.71 & $7.39 \mathrm{ab}$ \\
\hline 50 & 0.47 & 3.85 & $2.29 \mathrm{ab}$ & 2.29 & $7.59 \mathrm{ab}$ \\
\hline 80 & 0.19 & 1.75 & $0.98 \mathrm{~b}$ & 0.98 & $6.31 \mathrm{~b}$ \\
\hline
\end{tabular}

(1) $n s=$ not significant, ${ }^{*}=$ significant at $5 \%$.

plants cultivated in full sun were more susceptible to oviposition and produced a higher number of lateral buds. The higher number of oviposition holes observed on the pseudostems of the heliconias in full sun could indicate an increase in the grasshopper population, depending on the viability of the eggs deposited. Data for C. f. frenatum about egg laying was not found, but the congener Cornops aquaticum (Bruner) has good reproductive capacity and deposits an average of 13.4 eggs per clutch inside holes made by the female at the base of the petiole of Eichhornia crassipes (Mart.) (Pontederiaceae), making it a potential control agent of this aquatic plant (VIEIRA \& SANTOS, 2003). Contrarily, under $80 \%$ shade there was a lower number of oviposition holes, which is a positive result (from a management point of view) in relation to reducing the population level of the grasshopper. However, under this condition there were fewer lateral buds, differing significantly from the full sun condition.

In the phenology of heliconias, each lateral bud (shoot) can differentiate into a flower, which is an important factor in the commercial production of these tropical flowers. Therefore, the conditions that favor the production of new shoots are an important aspect in the production of these plants because heliconias with more shoots tend to produce more flowers. The analysis of the effect of shade on the grasshopper population and the phytotechnical aspects of the plants evaluated suggested that intermediate levels of shade (30\% and 50\%) are good options when cultivating the heliconias in areas where C. f. frenatum occurs. SOUZA et al. (2016) observed, when free of pests, $50 \%$ shade from screen is efficient to cultivate desirable plants of the 'Golden Torch' hybrid in containers. In addition; although, plants in full sun had more shoots, at the end of the experiment they were smaller and the color of their leaves and flowers tended to be less intense than those cultivated under conditions of $30 \%$ and $50 \%$ shade. Overall, it was observed that in the months with higher solar incidence, which is common in northeastern Rio de Janeiro, the leaves in full sun burned.

Hypothesis H2: there were differences among the heliconia species evaluated, including significant differences among the species for all the variables analyzed (Table 2). Heliconia wagneriana was the most visited by the adults and nymphs of $C$. $f$. frenatum, and oviposition by the grasshopper was the highest on this heliconia species (Figure 1). These results indicate that $C$.f. frenatum prefers this heliconia species compared to the others evaluated, which could be related to food and oviposition, as well as mating place and refuge, independent of the level of shade. Contrary results were reported for $H$. psittacorum for the grasshopper variables analyzed. Probably, the difference in susceptibility to oviposition by the grasshopper is the result of defense mechanisms related to morphological characteristics of the species. Compared to $H$. wagneriana, it was observed that $H$. psittacorum has more rigid pseudostem and leaf tissues that could make endophytic oviposition difficult for $C$. $f$. frenatum females. Insects might also prefer less fibrous leaves for food, justifying the fewer individuals of C.f. frenatum on H. psittacorum. To confirm this, future research is needed to evaluate the plant resistance types, mainly non-preference for feeding or oviposition, knowing that structural characteristics of the plants (e.g., fiber content in tissues) could be the cause of these resistance types to insects (LARA, 1991).

The hybrid 'Golden Torch' and H. stricta were statistically similar in relation to the number of $C$. f. frenatum individuals and oviposition holes, suggesting that both have similar visitation levels of adults and nymphs and are preferred the same by the grasshopper 
Table 2 - Average values of the Friedman ANOVA and Kendall's concordance coefficient $(W=0.88$; N=4, DF=3) for the number of adults $(\mathrm{A})$, nymphs $(\mathrm{N})$ and oviposition holes $(\mathrm{O})$ of Cornops frenatum frenatum and the flower stems $(\mathrm{F})$ and lateral buds $(\mathrm{B})$ of the heliconias, from March 2012 to February 2013, in Santo Antônio de Pádua, RJ.

\begin{tabular}{|c|c|c|c|c|c|}
\hline \multirow[t]{2}{*}{ Species } & \multicolumn{5}{|c|}{ 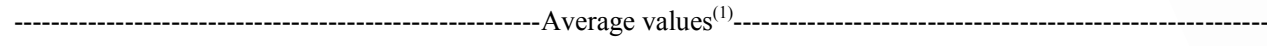 } \\
\hline & $\mathrm{A}^{*}$ & $\mathrm{~N}^{*}$ & $\mathrm{O}^{* *}$ & $\mathrm{~F}^{*}$ & $\mathrm{~B}^{*}$ \\
\hline 'Golden Torch'(2) & $0.24 \mathrm{ab}$ & $1.53 \mathrm{ab}$ & $0.62 \mathrm{ab}$ & $0.61 \mathrm{a}$ & $9.74 \mathrm{a}$ \\
\hline H. stricta & $0.56 \mathrm{ab}$ & $1.79 \mathrm{ab}$ & $2.02 \mathrm{ab}$ & $0.02 \mathrm{bc}$ & $8.94 a b$ \\
\hline H. pittacorum & $0.08 \mathrm{~b}$ & $0.76 \mathrm{~b}$ & $0.32 \mathrm{~b}$ & $0.32 \mathrm{abc}$ & $5.94 \mathrm{~b}$ \\
\hline H. wagneriana & $0.76 \mathrm{a}$ & $7.17 \mathrm{a}$ & $8.87 \mathrm{a}$ & $0.05 \mathrm{c}$ & $6.15 \mathrm{ab}$ \\
\hline
\end{tabular}

$(1){ }^{*}=$ significant at $5 \%,{ }^{* *}=$ significant at $1 \%$. (2) H. psittacorum $x$ H. spathocircinata.

for oviposition. However, oviposition holes were three times higher in $H$. stricta compared to the hybrid.

For the production parameters, $H$. wagneriana showed low productivity in relation to the flowers produced during the study period. The hybrid 'Golden Torch' was the most productive heliconia, both in emission of flower stems and lateral buds, as observed by RODRIGUES (2010) under the conditions of Porto Velho, RO (Brazil). Strangely, potted $H$. psittacorum plants produced the fewest lateral buds, which differs from field observations (COSTA et al., 2006). Results demonstrated that this heliconia has restricted growth when cultivated in a container because its lateral buds are more spaced out compared to the other species studied. This was reflected in the various buds observed in the drainage holes of the containers with $H$. psittacorum.

\section{CONCLUSION}

Cornops frenatum frenatum occurs in Santo Antônio de Pádua, RJ (Brazil) as a defoliating grasshopper of the Heliconia species studied ( $H$. psittacorum, $H$. stricta, $H$. wagneriana and $H$. psittacorum x $H$. spathocircinata 'Golden Torch'). The intermediate levels of shade $(30 \%$ and $50 \%)$ are more adequate for producing the four heliconia species where $C$. $f$. frenatum occurs. The population of $C$. f. frenatum is larger on plants of $H$. wagneriana, which is more attractive to the adults and nymphs of $C$. f. frenatum and preferred more by the females for oviposition, contrary to $H$. psittacorum.

\section{ACKNOWLEDGEMENTS}

The authors thank Dr. Marcos Gonçalves Lhano (Universidade Federal do Recôncavo da Bahia, Cruz das Almas, BA, Brazil) by identification of the short-horned grasshopper.

\section{REFERENCES}

ADIS, J. et al. Distribution of Cornops grasshoppers (Leptysminae: Acrididae: Orthoptera) in Latin America and the Caribbean Islands. Studies on Neotropical Fauna and Environment, v.42, n.1, p.11-24, 2007. Available from: <http://dx.doi. org/10.1080/01650520600931719>. Accessed: May. 16, 2017.

ASSIS-PUJOL, C.V.; PUJOL-LUZ, J.R. Checklist of Caelifera (Acridoidea and Eumastacoidea) of Rio de Janeiro State (Orthoptera). EntomoBrasilis, v.7, n.2, p.134-150, 2014. doi: 10.12741/ebrasilis.v7i2.354.

BRAGA, C.E. et al. Cornops frenatum frenatum (Marchall, 1836) Orthoptera, Acrididae, Leptysminae): occurrence and oviposition on four species of Heliconia (Heliconiaceae) in Central Amazonia, Brazil. Amazoniana, v.19, n.3/4, p.227-231, 2007. Available from: $<$ http://web.evolbio.mpg.de/amazoniana/227-232\%20Nota\%20 Cientifica\%20\%20\%20\%20Braga.pdf $>$. Accessed: May. 16, 2017.

COSTA, A.S. et al. Number of shoots and area per clump of heliconia. Horticultura Brasileira, v.24, n.4, p.460-463, 2006. doi: $10.1590 / \mathrm{S} 0102-05362006000400013$.

LACTIN, D.J.; JOHNSON, D.L. Response of body temperature to solar radiation in restrained nymphal migratory grasshoppers (Orthoptera: Acrididae): influences of orientation and body size. Physiological Entomology, v.22, n.2., p.131-139, 1997. doi: 10.1111/j.1365-3032.1997.tb01150.x.

LARA, F.M. Princípios de resistência de plantas aos insetos. São Paulo: Ícone, 1991. 336p.

LEMOS, W.P. et al. Cornops frenatum frenatum (Marschall) (Orthoptera: Acrididae, Leptysminae) in crops of tropical flowers of Heliconia spp. in the State of Pará, Brazil. Entomotropica, v.25, n.1, p.43-47, 2010. Available from: $<$ http://www.entomotropica.org/index. php/entomotropica/article/view/264>. Accessed: May. 16, 2017.

LEMOS, W.P. et al. Cornops frenatum frenatum (Marchall) (Orthoptera: Acrididae): principal desfolhador em cultivos de Heliconia spp. (Heliconiaceae) no Estado do Pará. Belém: Embrapa Amazônia Oriental-CNPTU, 2006. 4p. (Embrapa Amazônia Oriental, Comunicado Técnico, 164). Available from: $<$ https://www.infoteca.cnptia.embrapa.br/infoteca/bitstream/ doc/409649/1/Com.tec.164.pdf>. Accessed: May. 16, 2017. 
MACHADO NETO, A.S.; JASMIM, J.M. Profile of production tropical flowers in Rio de Janeiro state. Revista Brasileira de Horticultura Ornamental, v.8, n.1, p.513, 2012. Available from: <https://ornamentalhorticulture. emnuvens.com.br/rbho/article/viewFile/688/498>. Accessed: May. 16, 2017.

MATTOS SOBRINHO, C.C. et al. Insects associated to heliconias cultivated in Southern Bahia. Magistra, v.24, p.57-62, 2012. Available from: <http://www2.ufrb.edu.br/magistra/documentos/ category $/ 58>$. Accessed: May. 16, 2017.

NEVES, M.F.; PINTO, M.J.A. Mapeamento e quantificação da cadeia de flores e plantas ornamentais do Brasil. São Paulo: OCESP, 2015. 122p. Available from: <http://ocesp.org. br/download/Livro_Mapeamento_e_Quantificacao_Cadeia_de_ Flores_FINAL.pdf $>$. Accessed: May. 16, 2017.

RIBEIRO, R.C. et al. New record of grasshopper (Orthoptera: Acrididae \& Romaleidae) defoliators and population dynamics of insects on crops of Heliconia spp. in the Amazon. Florida
Entomologist, v.96, n.1, p.225-228, 2013. Available from: <https:// doi.org/10.1653/024.096.0130>. Accessed: May. 16, 2017.

RODRIGUES, V.G.S. Avaliação de cultivares de Heliconia psittacorum nas condições de Porto Velho, Rondônia. Porto Velho: Embrapa Rondônia, 2010, 6p. (Embrapa Rondônia, Circular Técnica, 117). Available from: <https:/www.infoteca.cnptia.embrapa.br/ bitstream/doc/884141/1/ct117heliconia.pdf $>$. Accessed: May. 16, 2017.

SOUZA, R.R. et al. Growth and changes on morphology and physiology of heliconias according to different shading environments. Comunicata Scientiae, v.7, n.2, p.214-222, 2016. doi: 10.14295/CS.v7i2.884.

VIEIRA, M.F.; SANTOS A.C. Life cycle of Cornops aquaticum (Bruner, 1906) (Orthoptera: Acrididae: Leptysminae) and aspects of food behavior at Central Amazonia. Acta Amazônica, v.33, n.4, p.711-714, 2003. Available from: <http://dx.doi.org/10.1590/ S0044-59672003000400016>. Accessed: May. 16, 2017.

WARUMBY, J.F. et al. Principais doenças e pragas em flores tropicais no Estado de Pernambuco. Recife: SEBRAE, 2004. 98p. 